\title{
Effect of Grass-legume Intercropping on Dry Matter Yield and Nutritive Value of Pastures in the Eastern Cape Province, South Africa
}

\author{
Unathi Gulwa ${ }^{1, *}$, Nobulungisa Mgujulwa ${ }^{1}$, Solomon T Beyene ${ }^{2}$ \\ ${ }^{1}$ Eastern Cape Department of Rural Development and Agrarian Reform, Dohne Agriculture Development Institute (ADI), South Africa \\ ${ }^{2}$ Department of Livestock and Pasture Science, University of Fort Hare, South Africa
}

Copyright@2017 by authors, all rights reserved. Authors agree that this article remains permanently open access under the terms of the Creative Commons Attribution License 4.0 International License

\begin{abstract}
The Eastern Cape Province, South Africa is faced with inadequate quantity of livestock feed especially during the drier (winter) seasons. Forage legumes were over sown into natural grasses to determine their potential to improve feed quality and quantity. Four forage legumes namely: Trifolium vesiculosum (Arrowleaf clover), Lespedeza cuneata (sericea lespedeza), Trifolium repens (white clover) and Lotus corniculatus (birdsfoot trefoil) were intercropped with native grasses in the old arable land located in Lushington communal area in the Eastern Cape Province, South Africa. The treatments consisted of natural grasses growing in pure stands and native grasses intercropped with forage legumes grown under rain-fed conditions. Grasses and legumes were harvested for dry matter yield (DMY) once in spring 2013 (September-November), $\quad$ summer 2014 (December-February), autumn 2014 (March-May) and winter 2014 (June-August). Amongst the legumes, L. cuneata was more $(\mathrm{P}<0.05)$ productive than rest of the legumes. However, T. vesiculosum was the least $(\mathrm{P}<0.05)$ productive legume during the four seasons. Total dry matter $(\mathrm{TDM})$ yield was higher $(\mathrm{P}<0.05)$ during summer and lower during winter seasons, respectively. Grasses harvested in autumn had the highest $(\mathrm{P}<0.05) 12 \%$ crude protein (CP) than those harvested in winter which, had the lowest $4.6 \%$ CP content. Similarly, all legume pastures harvested in spring had superior $(\mathrm{p}<0.05) 10.8 \% \mathrm{CP}$, while those harvested in winter had the least 3.5\% CP. Likewise, forages harvested during the wet seasons (i.e. autumn and or summer) had improved $(\mathrm{P}<0.05)$ herbage micro nutrient content than those harvested in the drier (winter) season. Results of the study indicated that overall total dry matter yield of grass-legume mixtures was higher than that of sole natural grasses, with grasses constituting the major component of the herbage yield. Results from this study also indicated that forages produced in wetter seasons had superior biomass yield and nutritive value, respectively.
\end{abstract}

Keywords Total Dry Matter Yield, Dry Matter Yield, Crude Protein, Dry Matter Production

\section{Introduction}

Legume pastures are the basis of pasture and animal production systems in many parts of the world including South Africa, and consequently, they present an alternative and supplementary source of nutrients for sheep and cattle in various agro ecological areas. Legumes are commonly included in livestock and cropping systems through intercropping. Intercropping is a multiple cropping practice, which involves growing two or more crops in proximity. Intercropping forage legumes with grasses presents a potential to increase productivity, herbage nutritive value and resource efficiency. Legumes also improve the nutritive value of the low quality native pastures grown with them and are important component of farming system since they have high nutritive value and able to rehabilitate nutrient depleted soil (Hayat et al. [1]). There are two environmental factors mainly limiting pasture productivity in most semi-arid environments and these are water availability and soil nutrient deficiencies, particularly nitrogen (N) and phosphorus (P) supply (Lopez-Gutierrez. [2]). In this context, production systems incorporating legume fodder crops can play a fundamental role in improving soil fertility, allowing efficient water and nutrient use, and bridging the fodder flow gap that is prevalent during dry spells (Evans et al. [3]). Legume species and cultivars differ in their $\mathrm{N}$ fixation capacity and in the $\mathrm{N}$ content in the stem and root and consequently, in the capacity to contribute $\mathrm{N}$ to the soil (Ovalle et al.; Campillo et al.; Fillery, Urzúa, Peoples et al. [4-8]). The transfer of $\mathrm{N}$ from legumes to associated species in the pasture or to other crops in a legume-crop rotation system 
mainly occurs through the decomposition of their residues (Peoples et al., Danso et al. [8, 9]). Forage legume mixtures increase plant diversity, productivity and pasture persistence (Tilman et al. [10]). A key aspect in the design of pasture mixtures is the correct selection of species and cultivars, which must combine different reproductive strategies and be able to establish and maintain an adequate seed bank in the soil for self-seeding after the crop face in a pasture-crop rotation (Norman et al., Ovalle et al., Loi et al. $[11,4,12])$.

In Africa, small scale mixed crop-livestock is one of the common agricultural practices. Most small-scale farmers do not afford the high mineral fertilizer prices to fertilize the crop and pasture lands to increase productivity. Therefore, legume inclusion in these farming systems can play a vital role in sustaining crop and livestock production, and in maintaining or improving the fertility of marginal lands (Serraj and Adu-Gyamfi [13]). More than $75 \%$ of the chemical fertilizers utilized in Africa are imported and this exerts more pressure on foreign exchange (Chianu et. al. [14]). Due to this high cost of fertilizer and the limited market infrastructure for farm inputs, both extension and research efforts at present are focused to integrated nutrient management, in which legumes play a vital role (Serraj and Adu-Gyamfi [13]).

Like the rest of African countries, farming systems in many communal areas of South Africa is small scale, mixed crop-livestock systems. Livestock system is composed of cattle, goat and sheep. These livestock require good quality pastures to maintain satisfactory animal performance throughout the year. However, achieving and maintaining the satisfactory animal performance is a major challenge in summer rainfall areas like the Eastern Cape Province due to the shortage of fodder and poor quality of natural grasses during the winter or dry season. Therefore, legume production to supplement the natural pastures with protein should form part of the animal production or farming systems in the Eastern Cape province of South Africa. Forage legumes also present a cheaper feed supplement than commercial concentrates and can be grown by smallholder farmers (Njarui and Wandera [15]). To evaluate the potential of these legumes, better knowledge is required on how to include the legumes into existing farming systems. The aim of the study was to determine the effect of forage legume inclusion on the dry matter yield (DMY) production and quality of pastures in four seasons in the semi-arid Lushington communal area in the Eastern Cape Province, South Africa.

\section{Materials and Methods}

The study was conducted at Lushington communal area located at $26^{\circ} 82^{\prime} 00^{\prime \prime} \mathrm{S} ; 32^{\circ} 64^{\prime} 00^{\prime \prime} \mathrm{E}$ and $956 \mathrm{~m}$ altitude, in the Eastern Cape Province, South Africa. The communal area belongs to the Amothole district municipality, which stretches from the coast through a large part of the former Transkei and inland across the Amatola Mountains. Lushington falls in the Dohne sourveld, receiving a mean annual rainfall of $600-700 \mathrm{~mm}$. The soils in this communal area classified as loamy sand known as Wesleigh soil forms. Cattle, goats and sheep are the major livestock kept in the area, as is the case in most communal areas of the Eastern Cape Province. After selecting an arable land, which was not cultivated for at least five years in the communal area, an area of one hectare was fenced off. Selection was based on authorization by the communal farmers, after extensive social facilitation that was done before the commencement of the trial. Thirty plots measuring $5 \mathrm{~m} \times 2.5 \mathrm{~m}$ were marked. The space between the plots was $2.5 \mathrm{~m}$. The experimental site consisted of the areas without legumes (control plots) and 14 legume species planted in two replicates in a randomized complete block design (RCBD). Prior planting, seeds were mixed with the appropriate inoculant by hand. The legumes that were initially planted in the site were: Aeschynomene falcata (crownvetch), Lotus corniculatus (birdsfoot trefoil), Lotus subbiflorus, Lespedeza cuneata (sericea lespedeza), Lotononis bainesii, Trifolium repens (white clover), Medicago sativa (lucerne), Desmodium intortum (Greenleaf desmodium), Lotus hispidus, Trifolium pratense (Red clover), Biserrula pelecinus, Trifolium hirtum (rose clover), Trifolium vesiculosum (arrowleaf clover) and Medicago polymorpha and medicago truncatula ( Medic mix).

Planting was done by over sowing legumes into the natural pastures (grasses) using an Aitchison Mini seeder, (six row no-till pasture seeder) at $5 \mathrm{~kg} / \mathrm{ha}$ seeding rate. Based on the soil analysis results of samples that were taken before planting, phosphors $(\mathrm{P})$ level was corrected to the level of $20 \mathrm{mg} \mathrm{P} / \mathrm{kg}$ by applying (50kg superphosphate) per hectare at planting. The $\mathrm{P}$ application was a once off application during planting and planting was done in March and October 2007. All legumes were subjected to grow under rain fed conditions. Plant sampling was done once in spring 2013(September-November), summer 2014 (December-February), autumn 2014 (March-May) and winter 2014 (June-August) seasons, respectively. The average rainfall during the sampling period was $45 \mathrm{~mm}$, $58 \mathrm{~mm}, 37 \mathrm{~mm}$ and $30 \mathrm{~mm}$ during spring, summer, autumn and winter seasons, respectively. Average minimum and maximum temperatures for Lushington ranged between 13 $-26^{\circ} \mathrm{C}$. In 2011, it was observed that of the fourteen species that were planted initially, only four species persisted throughout the years. These species were Trifolium vesiculosum (arrowleaf clover), Lespedeza cuneata (sericea lespedeza), Trifolium repens (white clover) and Lotus corniculatus (birdsfoot trefoil). Herbaceous material from the grass-legume mixture and control plots were sampled to determine dry matter production and their nutritive value. The aboveground biomass production [(dry weight (g)/wet weight (g) x 100)/1000] of the four tested 
legumes was determined from five quadrants $\left(0.5 \mathrm{~m}^{2}\right)$ per plot, randomly distributed in each plot. In each quadrant, grasses, forbs and legumes were harvested once per season, separated and placed in paper bags. The samples were weighed to determine the fresh matter yield and oven dried at $65^{\circ} \mathrm{C}$ for 72 hours. Dried samples were weighed to determine the dry matter weight. The oven-dried samples were ground to pass through a $2 \mathrm{~mm}$ sieve and stored in brown paper bags at room temperature pending chemical analysis. Plant macronutrient analysis for $\mathrm{Mg}, \mathrm{K}$ and $\mathrm{Ca}$ was done using a wet digestion of $5 \mathrm{~g}$ of sample in $5 \mathrm{ml}$ nitric acid $\left(\mathrm{HNO}_{3}\right)$ and $3 \mathrm{ml}$ of perchloric acid $\left(\mathrm{HCIO}_{4}\right)$ digested on an aluminum digestion block. The elements in the digest were measured using an Analytikjena NovAA400 absorption spectrometer. The samples for the elements $\mathrm{Ca}, \mathrm{Mg}, \mathrm{K}$ and $\mathrm{Na}$ were diluted 20 fold with distilled water and strontium nitrate $\left[\mathrm{Sr}\left(\mathrm{NO}_{3}\right)_{2}\right]$ added to suppress ionization. Microelements ( $\mathrm{Zn}, \mathrm{Cu}, \mathrm{Mn}$ and $\mathrm{Fe}$ ) were analyzed undiluted. Total $\mathrm{N}$ was analyzed using $5 \mathrm{~g}$ of digested sample for 3 hours on an aluminum digestion block at $360^{\circ} \mathrm{C}$ after the addition of $10 \mathrm{ml}$ sulphuric acid $\left(\mathrm{H}_{2} \mathrm{SO}_{4}\right)$ in the presence of selenium (Se) catalyst. Nitrogen levels were determined calorimetrically using a SKALAR continuous flow analyzer (Williams [16]). All plant samples were analyzed at the Dohne Analytical services laboratory. Sample collection and analysis were done once in spring 2013, summer 2014, autumn 2014 and winter 2014 seasons. All data were analyzed using two-way analysis of variance (ANOVA) of the generalized linear model (GLM) procedure of SAS (2001) statistical program. Treatment (species) and season were the main factors, while plant DMY and nutrient content variables were the dependent variables.

\section{Results}

Legume intercropping and season interacted significantly to influence the dry matter yield (DMY) of legumes, grasses and the total herbaceous cover. Comparing grass dry matter production within each season, T. vesiculosum planted plots yielded the highest grass dry matter (DM) in summer, but in autumn, L. corniculatus planted plots and the control plots had the highest and statistically similar grass DM production. In winter and spring, $T$. repens and $L$. corniculatus planted plots yielded respectively higher grass DM than the other treatments. Comparing within each treatment across seasons, trends showed slight difference between treatment plots. In the control treatments, grass DMY was statistically similar and higher in the summer, autumn and winter seasons. Plots planted with $L$. cuneata, $T$. vesiculosum and $L$. corniculatus had highest grass DM yield in summer, whereas in the remaining seasons, yield was statistically similar. For $T$. repens plots, grass DM yield was significantly high in summer followed by winter season
(Table 1). Comparing legume species within each season, $L$. cuneata had the highest $(\mathrm{P}<0.05)$ DM yield in all seasons; $T$. repens had the lowest DM yield in summer and spring, respectively. Considering the performance of each species across seasons, the following results were found: $L$. corniculatus and $T$. repens produced the highest $(\mathrm{P}<0.05)$ DM during the summer season, and the lowest during winter and spring seasons, respectively. The yield of $L$. cuneata also showed seasonal variations being highest $(\mathrm{P}<$ $0.05)$ in summer and spring seasons and lowest in autumn and winter seasons (Table 2).

Comparing total dry matter (TDM) production between treatments in each season, the following results were found: In summer, $L$. cuneata planted plots had the highest values and the control plots had the least. In autumn, all treatments except $T$. repens planted plots had similar and high DM production. Contrary, in winter, DM production was highest in T. repens planted plots. In spring, L. corniculatus and $L$. cuneata planted plots yielded the highest DM production and the control plots yielded the least DM. All legume treated plots had the highest DM yield in summer seasons. For $L$. corniculatus and $L$. cuneata planted plots, DM yield was lowest in winter, whereas for the remaining legume treatments, DM yield was lowest in spring (Table 3).

The CP content of grasses varied $(\mathrm{P}<0.05)$ among the treatments. Grasses harvested from T. repens had greater CP content while those harvested from the control plot had the least CP content. Similarly, grasses harvested from the $T$. repens plot produced higher $(\mathrm{P}<0.05) \mathrm{K}$ content than grasses harvested from other treatments whereas grasses harvested from the control plot produced the least $\mathrm{K}$ content. A similar trend was observed in the Mg content of grasses where $\mathrm{Mg}$ was superior $(\mathrm{P}<0.05)$ in the grasses harvested from the $T$. repens plot and lower in the control plot. The grass $\mathrm{Ca}$ content was higher $(\mathrm{P}<0.05)$ in the control, $T$. repens and $L$. cuneata plots, respectively and lower in the $T$. vesiculosum and $L$. corniculatus plots, respectively (Table 4). Grass harvested in autumn had higher $(\mathrm{P}<0.05) \mathrm{CP}$ content whereas, grass harvested during winter had lower CP content. The legume CP content was higher $(\mathrm{P}<0.05)$ during summer season than all other seasons and reached the lowest level during winter. During autumn grasses had higher $(\mathrm{P}<0.05) \mathrm{K}$ content while they had lower $\mathrm{K}$ content during winter, spring season resulted to the highest $(\mathrm{P}<0.05)$ while winter season harvest resulted to the lowest legume K levels. The highest $(\mathrm{P}<0.05)$ grass $\mathrm{Ca}$ level was measured during spring and autumn seasons respectively; while the lowest grass Ca levels were measured in summer and winter seasons, exclusively. Contrary, the grass $\mathrm{Mg}$ level was higher $(\mathrm{P}<0.05)$ during autumn while lower during spring. The legume Mg level reached the highest $(\mathrm{P}<0.05)$ level during spring while the lowest level was determined during autumn season (Table 5). 
Table 1. Mean values of grass DM yield (kg/ha) produced in Lushington per season

\begin{tabular}{|c|c|c|c|c|}
\hline Grass DM & Summer & Autumn & Winter & Spring \\
\hline Control & $1029^{\mathrm{aC}}$ & $1400^{\mathrm{aA}}$ & $1188^{\mathrm{aB}}$ & $349^{\mathrm{bD}}$ \\
\hline L. corniculatus & $2649^{\mathrm{aB}}$ & $1402^{\mathrm{bA}}$ & $1225^{\mathrm{bB}}$ & $1172^{\mathrm{bA}}$ \\
\hline T. repens & $2689^{\mathrm{aB}}$ & $781^{\mathrm{cB}}$ & $1603^{\mathrm{bA}}$ & $657^{\mathrm{cC}^{\mathrm{B}}}$ \\
\hline T. vesiculosum & $3026^{\mathrm{aA}}$ & $1055^{\mathrm{bA}}$ & $1224^{\mathrm{bB}}$ & $820^{\mathrm{bB}}$ \\
\hline L. cuneata & $1882^{\mathrm{aC}}$ & $777^{\mathrm{bB}}$ & $613^{\mathrm{bC}}$ & $557^{\mathrm{bC}}$ \\
\hline Standard error & & $\mathbf{4 3 0}$ & & \\
\hline
\end{tabular}

Different small letter superscripts within the same row depict significant difference $(\mathrm{P}<0.05)$ between seasons within each treatment. Different capital superscripts within the same column depict significant difference $(\mathrm{P}<0.05)$ between treatments within each season.

Table 2. Mean values of legume DM yield (kg/ha) produced in Lushington per season

\begin{tabular}{|c|c|c|c|c|}
\hline Legume DM & Summer & Autumn & Winter & Spring \\
\hline L. corniculatus & $706^{\mathrm{aB}}$ & $127^{\mathrm{bB}}$ & $114^{\mathrm{cB}}$ & $188^{\mathrm{bB}}$ \\
\hline T. repens & $315^{\mathrm{aC}}$ & $127^{\mathrm{bB}}$ & $125^{\mathrm{bB}}$ & $86^{\mathrm{cC}}$ \\
\hline T. vesiculosum & $154^{\mathrm{aD}}$ & $101^{\mathrm{aB}}$ & $101^{\mathrm{aB}}$ & $167^{\mathrm{aB}}$ \\
\hline L. cuneata & $1150^{\mathrm{aA}}$ & $449^{\mathrm{bA}}$ & $315^{\mathrm{bA}}$ & $907^{\mathrm{aA}}$ \\
\hline Standard error & & $\mathbf{8 6}$ & & \\
\hline
\end{tabular}

Different small letter superscripts within the same row depict significant difference $(\mathrm{P}<0.05)$ between seasons within each treatment. Different capital superscripts within the same column depict significant difference $(\mathrm{P}>0.05)$ between treatments within each season.

Table 3. Mean values of TDM yield (kg/ha) produced in Lushington per season

\begin{tabular}{|c|c|c|c|c|}
\hline TDM yield & Summer & Autumn & Winter & Spring \\
\hline Control & $1110.40^{\mathrm{bD}}$ & $1536.80^{\mathrm{aA}}$ & $1309.60^{\mathrm{aB}}$ & $412.16^{\mathrm{cD}}$ \\
\hline L. corniculatus & $3713.80^{\mathrm{aB}}$ & $1560.60^{\mathrm{bA}}$ & $1370.20^{\mathrm{cB}}$ & $1586^{\mathrm{bA}}$ \\
\hline T. repens & $3160.80^{\mathrm{aC}}$ & $939.60^{\mathrm{cB}}$ & $1759.00^{\mathrm{bA}}$ & $827.20^{\mathrm{cC}}$ \\
\hline T. vesiculosum & $3405.80^{\mathrm{aC}}$ & $1354.00^{\mathrm{bA}}$ & $1187.60^{\mathrm{bC}}$ & $1071.80^{\mathrm{cB}}$ \\
\hline L. cuneata & $3493.40^{\mathrm{aA}}$ & $1328.40^{\mathrm{bA}}$ & $993.24^{\mathrm{cC}}$ & $1558.80^{\mathrm{bA}}$ \\
\hline Standard error & & $\mathbf{4 1 2 . 1 6}$ & & \\
\hline
\end{tabular}

Different small letter superscripts within the same row depict significant difference $(\mathrm{P}<0.05)$ between seasons within each treatment. Different capital superscripts within the same column depict significant difference $(\mathrm{P}>0.05)$ between treatments within each season.

Table 4. The mean values of forage CP and macronutrient content produced in Lushington

\begin{tabular}{|c|c|c|c|c|c|c|}
\hline Nutrients & Species & Summer & Autumn & Winter & Spring & SE \\
\hline CP $\%$ & Grass & $12.4^{\mathrm{a}}$ & $12.5^{\mathrm{a}}$ & $4.6^{\mathrm{c}}$ & $7.8^{\mathrm{b}}$ & 0.14 \\
\hline & Legume & $7.63^{\mathrm{b}}$ & $5.18^{\mathrm{c}}$ & $3.5^{\mathrm{d}}$ & $10.8^{\mathrm{a}}$ & 0.14 \\
\hline $\mathrm{K} \%$ & Grass & $0.61^{\mathrm{b}}$ & $0.90^{\mathrm{a}}$ & $0.08^{\mathrm{c}}$ & $0.56^{\mathrm{b}}$ & 0.11 \\
\hline & Legume & $0.47^{\mathrm{b}}$ & $0.47^{\mathrm{b}}$ & $0.07^{\mathrm{c}}$ & $0.74^{\mathrm{a}}$ & 0.11 \\
\hline Ca $\%$ & Grass & $1.30^{\mathrm{b}}$ & $1.50^{\mathrm{a}}$ & $1.30^{\mathrm{b}}$ & $1.50^{\mathrm{a}}$ & 0.19 \\
\hline & Legume & $1.70^{\mathrm{a}}$ & $1.50^{\mathrm{b}}$ & $1.80^{\mathrm{a}}$ & $1.50^{\mathrm{b}}$ & 0.19 \\
\hline Mg \% & Grass & $1.78^{\mathrm{b}}$ & $2.24^{\mathrm{a}}$ & $0.94^{\mathrm{c}}$ & $0.87^{\mathrm{c}}$ & 0.17 \\
\hline & Legume & $0.94^{\mathrm{b}}$ & $0.75^{\mathrm{b}}$ & $0.78^{\mathrm{b}}$ & $1.87^{\mathrm{a}}$ & 0.17 \\
\hline
\end{tabular}

Different small letter superscripts within the same row depict significant difference $(\mathrm{P}<0.05)$ between seasons within each treatment. Different capital superscripts within the same column depict significant difference $(\mathrm{P}>0.05)$ between treatments within each season. 
Table 5. The mean values of forage micronutrient produced in Lushington per season

\begin{tabular}{|c|c|c|c|c|c|c|}
\hline Nutrients & Species & Summer & Autumn & Winter & Spring & SE \\
\hline \multirow[t]{2}{*}{ Zn (ppm) } & Grass & $12.42^{\mathrm{b}}$ & $12.53^{\mathrm{a}}$ & $4.45^{\mathrm{d}}$ & $7.94^{\mathrm{c}}$ & 3.50 \\
\hline & Legume & $8.61^{b}$ & $5.13^{\mathrm{c}}$ & $3.59^{d}$ & $10.51^{\mathrm{a}}$ & 3.50 \\
\hline \multirow[t]{2}{*}{$\mathrm{Cu}(\mathrm{ppm})$} & Grass & $18.59^{c}$ & $19.63^{b}$ & $13.41^{\mathrm{d}}$ & $25.16^{\mathrm{a}}$ & 2.20 \\
\hline & Legume & $20.78^{a}$ & $19.82^{\mathrm{b}}$ & $12.52^{\mathrm{d}}$ & $13.76^{\mathrm{c}}$ & 2.20 . \\
\hline \multirow[t]{2}{*}{ Mn (ppm) } & Grass & $178.51^{\mathrm{c}}$ & $191.23^{b}$ & $155.64^{d}$ & $234.67^{\mathrm{a}}$ & 16.78 \\
\hline & Legume & $178.51^{b}$ & $191.23^{\mathrm{a}}$ & $155.64^{c}$ & $121.09^{d}$ & 16.78 \\
\hline \multirow[t]{2}{*}{$\mathrm{Fe}(\mathrm{ppm})$} & Grass & $5.23^{b}$ & $4.64^{\mathrm{c}}$ & $13.46^{\mathrm{a}}$ & $3.42^{d}$ & 1.30 \\
\hline & Legume & $3.69^{c}$ & $3.38^{d}$ & $13.07^{\mathrm{a}}$ & $3.93^{\mathrm{b}}$ & 1.30 \\
\hline
\end{tabular}

Different small letter superscripts within the same row depict significant difference $(\mathrm{P}<0.05)$ between seasons within each treatment. Different capital superscripts within the same column depict significant difference $(\mathrm{P}>0.05)$ between treatments within each season.

\section{Discussion}

Legume intercropping had an effect on forage DMY. In general, it was observed that the grass-legume mixture plots produced more yield in comparison with the grass only (control) plots during the four seasons. In the current study, greater TDM was measured in the $L$ cuneata legume plot whereas the lowest TDM yield was recorded in the control plot. This finding is in agreement with the study of (Sturludottir et al. [17]) that was conducted in Northern Europe and Canada which, reported higher yield in the legume-grass mixtures than monoculture treatments. The authors reported that on average, the legume-grass mixture plots had 9\%, 15\% and 7\% more DMY than the most productive monoculture in the first, second and third year respectively. The attainment of high DMY in the grass-legume mixture plots may be attributed to beneficial effects of mixing grasses and legumes and also from the differences in the seasonal growth pattern between the grass and legume species (L€ uscher et al.[18]) or across years. The difference in growth patterns of legumes is reported to have a potential of leading to efficient use of resources such as light when grown in a mixture than when grown separately. All these different functional traits could contribute to positive interactions between the species resulting in higher yields for mixtures in comparison to monocultures (Nyfeler et al. [19]).

As anticipated, season had a significant effect on DMY of both grass and legumes with highest DMY recorded in summer. These results concur with the findings of (Njoka-Njiru et al. [20]), who reported the attainment of higher and lower DMY during the wet and dry seasons, respectively. The variation in seasonal dry matter production was associated with phenological development of plants. The reduction of DMY during the drier season is attributed to low soil moisture availability for plant growth and dependence of plants to residual moisture. Introduction of legumes significantly affected the CP content of forages. Grasses harvested from $T$. repens plot had the highest CP content followed by $T$. vesiculosum plot whereas grasses harvested from the control plot had the lowest CP content. The findings of this study correspond to the results of (Eskandari et al. [21]), who reported that grasses grown in Intercropping with legumes contained a higher $\mathrm{CP}$ content than grasses harvested from the monoculture planted plots. This suggests that legumes grown alongside non-legume plants increase the $\mathrm{N}$ uptake of the companion plants by partitioning the atmospheric fixed $\mathrm{N}$ by legumes to the non -nitrogen fixing plants grown in association with them. (Ojo et al. [22]) also reported higher CP levels on Panicum maximum intercropped with Lablab purpureus in a study they conducted at the Federal University of Agriculture in Nigeria.

In this study, significant differences in forage $\mathrm{CP}$ were also recorded between the four legumes species. Concentrations of nutrients in forage plants are dependent upon the interaction of a number of factors. These factors include the following: the physiology of the plant, physical and chemical compounds of the plant (tannins, cellulose and crude fibre), season and soil quality in which the forges are grown. Species like $L$. cuneata that are known to have high tannin content and a tendency to accumulate lignin, become less digestible and have low CP content as the plant matures. Grass CP level showed the following seasonal sequence: autumn $>$ summer $>$ spring $>$ winter while legume CP content showed the following seasonal order: spring $>$ summer $>$ autumn $>$ winter. In partial agreement with these findings, (Onyeonagu and Eze [23]) reported that nutritional values of forage species were lower during the dry season (winter) compared to the wet season (spring-autumn). The decline in the CP levels during the drier season in comparison with the wetter season was attributed to the decline of forage quality with advancing plant maturity.

As anticipated, legume introduction affected the macro element contents of grasses, as there were higher $\mathrm{K}, \mathrm{Ca}$ and $\mathrm{Mg}$ concentrations in grasses harvested from the grass- 
legume mixture plots in comparison to those harvested from the control plots. The findings from this study concur with the results from previous studies published by (Foster et al. [24]); who reported higher mineral contents in grass-legume mixture plots than in sole grass plots. Season also influenced the macro element content of both grasses and legumes harvested from the different treatment plots. Overall, the trends in grasses are as follows: autumn>summer>spring> winter for $\mathrm{K}, \mathrm{Ca}$ and $\mathrm{Mg}$, respectively. Conversely, trends for $\mathrm{K}$ and $\mathrm{Mg}$ in legumes are spring $>$ summer $>$ autumn $>$ winter. Generally, these results showed a trend that macronutrient content in both grass and legumes declines with advancement in season as the lowest macronutrient levels were measured during the driest season (winter). The findings of the current study are partly in agreement with the findings of a study that was conducted by (Weisany et al.[25]) who found that the nutrient concentration of grasses reached the highest level during summer (wet season), rapidly declined and reached the lowest level during the winter period (dry season). The Ca content of grass species reported in this study is below the range reported by (Mutanga et al. from South Africa, and above those reported by Ndebele et al. from Zimbabwe, Tefera et al. and Beyene and Mlambo [26-29]) from Swaziland semi-arid rangelands. The present study also recorded lower forage $\mathrm{K}$ values than the studies of (Mutanga et al. and Tefera et al. [26,28]) but higher values than the report of (Beyene and Mlambo [29]).

Except for Fe level, in this study, there was evidence of greater microelement levels in grasses harvested from the grass - legume mixture plots compared to the control plots. These findings are in agreement with the studies of (Lindstrom [30]) who reported that grass-legume mixture plots had higher micronutrient accumulation than monoculture grass plots. These findings are also in agreement with the study of (Hogh-Jansen and Soegaard [31]), who found higher micronutrient levels in grass legume mixture plots than pure grass stands. Various legume species harvested from different plots also showed great differences in their microelement concentration. These, findings are in line with the results published from previous studies, which indicated that it is difficult to make conclusions regarding the definite species differences since the plant micronutrients are influenced by various factors. These factors are species phenological development, season of harvest, botanical composition, weather, fertilizing, harvest regime, and available soil micronutrient concentrations, which are affected by soil properties (Roche et al and Schenk. [32,33]).

Season also had an effect on both grass and legume micro nutrient levels. Except the elements $\mathrm{Fe}$ and $\mathrm{Mn}$, harvested legumes generally had the lowest microelement concentrations during winter season. All grasses had the least micronutrient concentration during the driest season (winter). These results are related to the results published by (Brink et al. [34]) who investigated the changes in forages micronutrient concentrations and concluded that some forage legumes' (e.g. red clover, white clover and lucerne) micronutrient concentrations decreased with time during phenological development. A concentration of $7-11 \mathrm{mg} / \mathrm{kg} \mathrm{Cu}$ is considered adequate for beef cattle (NRC, [35]), but all grass species in the present study had by far lower $\mathrm{Cu}$ values. On average basis, grasses showed $\mathrm{Mg}$ level lower than the normal requirements for beef cattle.

\section{Conclusions}

The results of the current study showed that legume introduction had a positive effect on the forages' overall DMY. Seasonal variation also affected the forage DMY production as there was high dry matter yield produced during the wetter (summer) season than the drier (winter) season. Legume treatment also influenced the chemical composition of forage species. The attainment of high CP, macro and micro nutrient content in the grass - legume mixture plots in comparison to the control confirm that mixing grasses with legumes improves herbage nutritive value. The superior forage quality (nutrient composition) and quantity harvested during the wetter season (summer, spring and autumn) in the current study confirm that availability of adequate moisture is key to optimum fodder production. Low nutrient content and dry matter yield of grasses obtained from the control plot suggest that incorporating forage legumes into grasses is crucial to ensure the provision of balanced diets that is essential for normal physiological functioning of ruminant animals. Therefore, legume inclusion into old arable lands or grasslands could positively affect animal performance, as animals grazing in mixed pastures would graze more improved forages for prolonged periods. The results of the study showed potential to produce high quality livestock feed of high nutritional quality by incorporating legumes into natural grasses. The attainment of higher legume CP levels in the Lespedeza cuneata plot and lower CP levels in the $T$. repens plot was attributed to the renowned tendency of $T$. repens (white clover) to transfer more of its atmospheric fixed nitrogen to the companion plant. The higher CP levels in the Lespedeza cuneata plot are ascribed to the structural advantage this legume possesses in terms of its root system. Its tap root system enables the legume to mobilize nitrogen from deep soil layers beside the atmospheric fixed nitrogen.

\section{REFERENCES}

[1] Hayat RS, Ali MT Siddique, and Chatha TH. 2008. Biological nitrogen fixation of summer legumes and their residual effects on subsequent rainfed wheat yield. Pakistan J. Bot. 40(2): 711-712. 
[2] Lopez-Gutierrez JC, Toro M and Lopez H. 2004. Seasonality of organic phosphorus mineralisation in the rhizosphere of the native savanna grass. Trachypogon plumosus. Soil Biology and Biochemistry.36:1675-1684.

[3] Evans J, Mcneill AM, Unkovich MJ, Fettell NA, Heenan DP. 2001. Net nitrogen balances for cool-season grain legume crops and contributions to wheat nitrogen uptake: a review. Austr. J. Exp. Agric.41: 347-359.

[4] Ovalle C., del Pozo A., Peoples M. and Lavín A., 2010. Estimating the contribution of nitrogen from legume cover crops to the nitrogen nutrition of grapevines using the ${ }^{15} \mathrm{~N}$ isotopic dilution technique. In: Plant and Soil, 334: 247-259.

[5] Campillo R, Urquiaga S, Pino I, and Montenegro A. 2003. Estimación de la fijación biológica de nitrógeno en 475 leguminosas forrajeras mediante la metodología del ${ }^{15} \mathrm{~N}$. Agric Téc (Chile) 63:169-179.

[6] Fillery IRP. 2001. The fate of biologically fixed nitrogen in legume -based dryland farming systems. A review: Aust. J. Exp. Ag. 41:361-381.

[7] Urzúa H. 2000. Benefits of symbiotic nitrogen fixation in Chile. International Journal of Agriculture and Natural Resources. Vol. 32.

[8] Peoples MB, Brockwell J, Herridge, DF, Rochester IJ, Alves, BJR, Urquiaga S, Boddey RM, Dakora FD, Bhattarai S, Maskey SL, Sampet C, Rerkasem B., Khan, DF, Hauggaard-Nielsen H. and Jensen ES. 2009. The contributions of nitrogen-fixing crop legumes to the productivity of agricultural systems. Symbiosis, 48(1-3): 117.

[9] Danso SKA, Hardarson G and Zapata F. 1993. Misconceptions and Practical problems in the use of $15 \mathrm{~N}$ soil enrichment techniques for estimating N2 fixation. Plant soil 152: $25-52$.

[10] Tilman D, Knops J, Wedin D, Reich P, Ritchie M and Siemann E. 1997. The influence of functional diversity and composition on ecosystem processes. Science.294:843:845.

[11] Norman HC, Masters DG, Rintoul AJ, Wilmot MG, Jayasena V, Loi A and Revel CK. 2005. The relative feeding value of a new pasture legume, eastern star clover (Trifolium dasyurum) compared with subterranean clover (Trifolium subterraneum). Australian Journal of Agricultural Research.56:637:644.

[12] Loi A, Cocks PS, Howieson JG and Carr. SJ. 2000. Hardseededness and pattern of softening in Biserrula pelecinus $L$, Ornithopus Compressus $L$ and Trifolium subterraneum L. Australian Journal of Agricultural Research. 50: 1073-1081.

[13] Serraj R and Adu-Gyamfi J. 2004. Role of symbiotic nitrogen fixation in the improvement of legume productivity under stressed environments. West African. Journal. Applied. Ecology. 6: 95-109.

[14] Chianu JN, Nkoya EM, Mairura FS, Chianu JN and Akinnifesi. 2011. Biological Nitrogen Fixation and socioeconomic factors for legume production in sub-Saharan Africa: A review. Agron. Sustainable Dev. 31:139-154.

[15] Njaru DMG and Wandera FP. 2004. The effect of cutting frequency on productivity of five herbaceous selected legumes and five grasses in the semi-arid tropical Kenya. Tropical grasslands. 38: 158-166.

[16] Williams S. 1984. Official methods of analysis of the AOAC. $14^{\text {th }}$ edition. AOAC. Arlington.

[17] Sturludottir E, Brophy C, Elanger GB, Gustavsson AM, Jørgensen M, Lunnan T, and Helgadotti, A. 2013. Benefits of mixing grasses and legumes for herbage yield and nutritive value in Northern Europe and Canada. The journal of the British Grassland society. 12037: 1-12.

[18] L€ uscher A, Fuhrer J. and Newton PCD. 2005. Global atmospheric change and its effect on managed grassland systems. In: McGilloway DA. (ed.). Grassland: a global resource. Wageningen. Academic Press: 251-264.

[19] Nyfeler D, Huguenin-Elie O, Suter M, Frossard E, Connolly J, Lüscher A.2009. Strong mixture effects among four species in fertilized agricultural grassland led to persistent and consistent transgressive overyielding. Journal of Applied Ecology. 46: 683-691.

[20] Njoka - Njiru EN, Njaru MG, Abdulrazak SA and Mureithi JG. 2006. Agricultura tropica et subtropica. 39(4):255-262.

[21] Eskandari H, Ghanbari A and Javanmard A. 2009. Intercropping of Cereals and Legumes for Forage Production. Notulae Scientia Biologicae. 1(1): 07-13.

[22] Ojo VOA, Dele TA, Amole UY, Adeoye SA, Hassan, JAO and Idowu OJ. 2013. Effect of intercropping Panicum Maximum var. Ntchisi and Lablab purpureus on the growth, yield and chemical composition of Panicum maximum var. Ntchisi at different harvesting times. Pakistan Journal of Biological Sciences. 10: 1-4.

[23] Onyeonagu CC and Eze SM. 2013. Proximate compositions of some forage grasses and legumes as influenced by season of harvest. African Journal of Agricultural Research. 8 (29):4033-4037.

[24] Foster A, Vera CL, Malhi SS and Clarke FR. 2014. Forage yield of simple and complex grass legume mixtures under two management strategies. Canadian. Journal. Of Plant Science. 94: 41-50.

[25] Weisany W, Raei Y and Allahverdipoor KH. 2013. Role of Some of the Nutrients in the Biological Nitrogen Fixation. Bulletin of Environment, Pharmacology and Life Sciences. 2 (4):77-84.

[26] Mutanga O, Prins HHT, Skidmore AK, Wieren, S van, Huizing H, Grant R, Peel M and Biggs H. 2004. Explaining grass-nutrients patterns in a savanna rangeland of southern Africa. Journal of Biogeography. 31:819:829.

[27] Ndebele N, Mtimuni JP, Mpofu IDT, Makuza S and Mumba P. 2005. The status of selected minerals in soils, forage and beef cattle tissues in sermi - arid region of Zimbabwe. Tropical Animal Health Production. 37:381-393.

[28] Tefera S, Mlambo V, Dlamini BJ, Koralagama KDN and Mould FL. 2009. Chemical composition and in vitro ruminal fermentation of selected grasses in the semi - arid savannas of Swaziland. African Journal of Range and Forage Science. 26 (1):9-17.

[29] Beyene ST and Mlambo V. 2012. Botanical and Chemical 
composition of common grass species around dip-tank areas in semi-arid communal rangelands of Swaziland Tropical and Subtropical Agroecosystems. 15 (1): 143-152.

[30] Lindstrom B. 2013. Micronutrients in Temperate Forage Crops Grown in Sweden: Species Differences and Effects of Phonological Development and Soil. Doctoral Thesis: 11-58.

[31] Hogh-Jensen H and Soegaard K. 2012. Robustness in the mineral supply from temporary grasslands. Acta Agriculturae Scandinavica Section B. Soil and Plant Science 62(1):79-90

[32] Roche JR, Turner LR, Lee JM, Edmeades DC, Donaghy DJ, Macdonald KA, Penno JW and Berry DP. 2009. Weather, herbage quality and milk production in pastoral systems 3 : Inter-relationships and associations between weather variables and herbage growth rate, quality and mineral concentrations. Animal Production Science. 49(3):211-221.

[33] Schenk HJ. 2006. Root competition: beyond resource depletion. Journal of Ecology. 94 (4):725-739.

[34] Brink M, Ramolemana GM and Sibuga KP (2006). Vigna subterranea (L.) Verdc. In: Brink M, Belay G, (Eds). Plant Resources of Tropical African. Cereals and pulses. PROTA Foundation, Wageningen, Netherlands. pp. 213-218.

[35] NRC (National Research Council). 1996. Nutrient requirements of beef cattle. $7^{\text {th }}$ edition. National Academy Press. Washington. DC. 